\title{
INFLITRASI NILAI KEMUHAMMADIYAHAN PADA STRUKTUR KAWASAN DAN DESAIN BANGUNAN KOTA DI SULAWESI SELATAN
}

\author{
Khilda Wildana Nur \\ Program Studi Arsitektur, Fakultas Teknik, Universitas Muhammadiyah Makassar, \\ Jl. Sultan Alauddin No. 259 Makassar 90221 \\ khildawildananur@unismuh.ac.id
}

\begin{abstract}
ABSTRAK. Penelitian ini menjabarkan eksistensi nilai Kemuhammadiyahan yang mempengaruhi aspek fisik dan non fisik kawasan kota, baik dalam bentuk tata ruang (spatial) maupun pada bangunan kepemilikan Muhammadiyah. Substansi penelitian diharapkan dapat membuka cakrawala dan pemikiran bahwa keterkaitan masa lalu dalam ajaran murni Islam yang telah berkembang sebelum era perancangan kota dan arsitektur modern. Penelitian ini menggunakan pendekatan sejarah dan fenomenologi dengan jenis penelitian kualitatif-eksploratif. Teknik pengumpulan data dilakukan dari data primer, data sekunder dimana pengambilan populasi melalui purposive sampling dan random sampling. Metode analisa yang digunakan antara lain metode fenomenologi dan sejarah dengan teknik sikronik dan diakronik reading serta memadukan metode urban morfologi dan tipologi. Kajian ini akan memberikan aplikasi penciptaan lingkungan yang terbangun berdasarkan pengamalan amal makruf nahi mungkar yang menjadi tujuan pendirian Muhammadiyah.
\end{abstract}

Kata kunci: Bangunan, Kawasan, Mamminasata, Muhammadiyah, Tipologi

ABSTRACT. This study describes the existence of the value of Kemuhammadiyahan which affects the physical and non-physical aspects of the city area, both in spatial form and in the ownership of Muhammadiyah's buildings. The substance of research is expected to be able to open knowledge and thoughts that the past linkages in the pure understanding of Islam which have developed before the era of urban design and modern architecture. This study uses a historical and phenomenological approach with a type of qualitative-explorative research. Data collection techniques were carried out from primary data, secondary data where the population was collected through purposive sampling and random sampling. The analytical methods used phenomenology and history methods with synchronous and diachronic reading techniques and integrating urban morphology and typology methods. This study will provide an application for the creation of an environment that is built based on the practice of charitable and moral merit which is the aim of the establishment of Muhammadiyah.

Keywords: Buildings, Regions, Mamminasata, Muhammadiyah, Typology

\section{PENDAHULUAN}

Kota-kota di Sulawesi Selatan memiliki sejarah pertumbuhan berbeda dengan kota tradisional lain di Jawa. Pada kota-kota di Jawa tumbuh dan berkembang dari kelompok permukiman tradisional, biasanya ditandai dengan adanya masjid, lapangan dan kampung kelompok etnis tertentu, seperti Kauman, Kampung Arab, Little Netherland, dan Pecinan. Kauman sangat identik sebagai pusat aktivitas dakwah Islam, seperti di Yogyakarta yang merupakan cikal bakal lahirnya Muhammadiyah.

Pada tahun 1929, konsep ajaran Muhammadiyah masuk di masyarakat Sulawesi Selatan dan menjadi ajaran konstituen yang dapat mencegah tergelincir dalam perbuatan syirik, khurafat dan bid'ah. Pergerakan dakwah Muhammadiyah yang cukup menonjol adalah pendirian sekolah, tempat kursus, rumah penyantunannya terhadap kaum fakir miskin dan anak-anak yatim, pengaturan sistem zakat, pemantapan cara-cara beribadah sesuai dengan sunnah Rasul, membawa paradigm baru bagi ummat Islam Sulawesi Selatan. Berdasarkan fakta empiris tersebut, diperlukan kajian apakah kota-kota di Sulawesi Selatan mengalamai inflitrasi dari eksistensi pergerakan Muhammadiyah.

Batasan masalah penelitian ini meliputi aspek keruangan (spatial), perancangan kota dan arsitektur yang akan dikaitkan dengan pergerakan Muhammadiyah di Provinsi Sulawesi Selatan. Untuk pemilihan batasan wilayah didasarkan dari aspek perencanaan dan perancangan kota dan mengacu pada Kawasan Strategis Nasional (KSN) dalam tata ruang Nasional. Lebih khusus lagi yang melingkupi wilayah Sulawesi Selatan yang tertuang pada Kawasan Perkotaan Mamminasata (Makassar-MarosSungguminasa-Takalar) yang merupakan kawasan pengembangan yang terbentuk 
akibat pengembangan Kota Makassar yang begitu pesat dan menyebabkan terjadinya aglomerasi antara tiga kota utama lainnya yaitu di Maros, Sungguminasa (Gowa) dan Takalar.

Pada umumnya riset yang telah dilakukan mengkaji tentang peranan Muhammadiyah dari aspek sosial kemasyarakatan mencakup bidang pendidikan, politik dan keagamaan. Penelitian ini menjadi tema dengan anatomi nilai Kemuhammadiyahan yang menjembatani insan Muhammadiyah dalam menjalankan aktivitas di kota sebagai ruang ekspresi dari kegiatan Kemuhammadiyahan. Penelitian sebelumnya juga telah ada yang terkait tentang peran dan kedudukan kampung Islam dalam lingkup kota seperti keberadaan Kauman di Yogyakarta dan di Pulau Jawa secara umum. Namun, kajian peran dan kedudukan kawasan nuansa Islami di luar Pulau Jawa masih terbatas, terutama yang menyangkut muatan ajaran dan tarekat.

\section{Perancangan Kota dan Kawasan Berkarakter}

Ada beberapa teori untuk menelusuri karakter kawasan dari perancangan kota. Suatu kawasan akan berkarakter kuat dari kontribusi penciptaan persepsi di dalamnya. Wijanarka mengungkapkan bahwa keserasian, kesesuaian, keserasian dan kesinambungan secara visual antara arsitektural dan urban designnya dapat terlihat dari urban morphology [1]. Urban morfologi melingkupi perbandingan lahan terbangun dan tidak terbangun (solid-void) pada kawasan. Penciptaan persepsi dalam lingkup lingkungan juga dapat diasosiasikan dengan ungkapan visual.

Dalam pengenalan suatu identitas, Lynch mengungkapkan dalam citra kota. Citra kota sebenarnya berdasarkan kualitas lingkungan yang dapat dikenali secara visual atau tampilan cityscape. Elemen-elemen citra tersebut berkaitan satu sama lain, distrik terstruktur dengan node, dibentuk dari edge, dan diaksentuasikan dengan landmark. Dengan mengeksplorasi teori tersebut, karakter kawasan dapat dieksplorasi orientasi dan identitasnya melalui elemen-elemen tersebut.

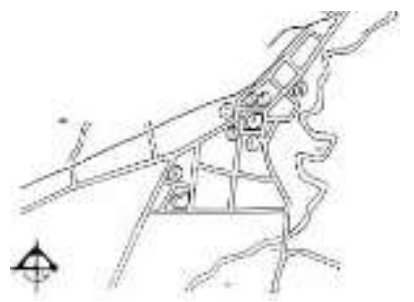

Struktuurkaart van Jember, schaal 1:25.000

A: Alun-Alun

C: Pecinan

2 : Mesjid

3 : Penjara

Gadai

5 : Asisten Residen
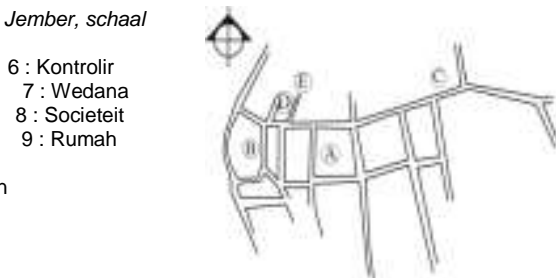

Kota Makassar, no scale A: Alun-Alun - Lapangan Karebosi

B: Fort Rotterdam - Pusa

Pemerintahan

: Mesjid Raya

: Societeit de Harmonie

E : Pecinan

Gambar 1. Perbandingan tatanan struktur kota di Jawa pada umumnya dan di Kota Makassar Sumber : Handinoto (1999), digambar ulang sesuai penelusuran peneliti (2017)

\section{Kauman sebagai Embrio Perkembangan Islam}

a. Kauman Yogyakarta

Darban mengemukakan bahwa terjadinya kampung Kauman melalui suatu perkembangan : (1) berdirinya Masjid Agung yang dilengkapi organisasi kemasjidan yang di dalamnya terdapat pejabat-pejabat dengan tugas-tugas khusus mengelola masjid, (2) pejabat-pejabat organisasi kemasjidan itu diberi tanah tempat tinggal di sekitar Masjid Agung, (3) berkumpulnya pejabat organisasi kemesjidan di sekitar masjid mendirikan sekelompok masyarakat baru yang berkembang jumlah anggotanya dan menjadi kampung dengan ciri khusus. [2]
Lebih lanjut Depari menyimpulkan beberapa faktor dominan yang mempengaruhi perubahan pola ruang kampung Kauman, yaitu: (1) Aspek politik: kebijakan kraton mempengaruhi proses transformasi kampung Kauman, mengingat peranan warga yang tinggal di dalam wilayah kampung Kauman sebagai abdi dalem yang berhubungan erat dengan birokrasi kraton. (2) Aspek sosial budaya: aktivitas sosial budaya warga setempat tidak lepas dari tanggung jawabnya terhadap kraton sehingga sebagian besar aktivitas warga senantiasa berhubungan dengan ritual keagamaan dan prosesi kraton. Nilai-nilai agama Islam yang mengatur perilaku hidup sehari- hari, berakuturasi dengan nilai modern sehingga mengakibatkan pola struktur 
ruang kampung bersifat hibrida; (3) Aspek ekonomi: semakin bertambahnya kebutuhan dan tuntutan hidup mendorong warga memodifikasi ruang hunian menjadi ruang usaha atau ditujukan untuk bisnis rumah sewa. [3]

\section{b. Kauman Solo}

Kauman di Kota Solo tidak terlepas dari keberadaan Mesjid Agung dan sejarah kelahirannya memiliki kaitan erat dengan Keraton Kasunanan Surakarta. Berdasarkan sejarah, warga Kauman awalnya bermata pencaharian sebagai abdi dalem ulama. Tapi dalam perkembangannya banyak yang menjadi karyawan, pedagang dan jasa. Selain itu juga banyak rumah yang membuka tempat usaha sebagai homestay bagi wisatawan. Hubungan sosial kemasyarakatannya terkait erat dengan pola permukimannya, hal ini terjadi karena jalan lingkungan yang terbentuk berupa lorong-lorong sempit, sehingga secara tidak langsung mempermudah komunikasi dan interaksi warga. Ciri arsitektural bangunan pada umumnya mengadaptasi dari rumah tradisional Jawa, seperti bentuk limasan, pelana dan joglo dan sesuai dengan kosmologi Jawa berorientasi Utara-Selatan. Selain bangunan dengan ciri tradisional Jawa, terdapat bangunan ragam colonial yang memadukan berbagai macam material konstruksi seperti kayu dan besi.

\section{c. Kampung Ampel, Surabaya}

Menurut Nur, pola spasial di Kawasan Ampel memiliki hirarki ruang yang membagi ruang berdasarkan publik, semi publik, privat. Saat ini, kawasan Ampel masih memiliki karakter ruang kota yang mengacu pada kota Islam, walaupun banyak nilai nilai dalam masyarakatnya yang berubah. Selain itu ada courtyard di tengah kantong permukiman, dalam hal ini adalah masjid Ampel yang dikelilingi oleh bangunan yang membentuk enclosure. [4]

Berdasarkan kajian tipomorfologi, konfigrasi solid dan void pada kawasan Ampel membentuk struktur ruang yang mengacu pada Islamic Planning, yaitu :

1) Bentuk struktur ruang ditujukan untuk memberi perlindungan terhadap wanita, ada jalan buntu dan jalan tembus sampai ke area masjid (courtyard, yang dikelilingi bangunan yang membentuk enclosur).

2) Setiap tempat memiliki kompetensi berjenjang dari public sampai ke privat, yang terhubung oleh jalan yang memiliki hirarki juga (berjenjang).
3) Struktur kawasan membentuk "Urban Labyrinth" (kota jejaring) dengan jalanjalan sempit yang kadang tertutup, lurus, berukuran pendek, membelok atau berputar, menembus dan berakhir pada courtyard. [4]

\section{d. Kauman Malang}

Rakhmawaty menyimpulkan bahwa karakteristik permukiman yang ditemukan di Kampung Kauman, dapat diklasifikasikan 2 macam jenis pola permukiman yang ada, yaitu pola permukiman linier mengikuti jalan dan pola permukiman berkumpul dan memusat. Pola spasial permukiman Kampung Kauman berdasarkan elemen pola spasial ditinjau melalui variabel hirarki. Hierarki pada sebuah permukiman pada umumnya terbagi berdasarkan tingkat sakralitas bangunannya, keterbukaan ruang tercermin melalui batas antar bangunan di Kampung Kauman, pola besaran ruang di Kampung Kauman terkesan sempit dan melorong, orientasi permukiman Kampung Kauman Kota Malang tidak memiliki acuan tertentu. [5]

\section{Muhammadiyah dan Arsitektur Islam}

Bangunan merupakan domain terbesar dalam pembentukan kota. Kehadiran bangunan sangat mempengaruhi spasial kawasan dan kota yang ditandai dengan tipologi bangunan. Hubungan tipologi bangunan dan kawasan yang demikian terkait ini maka dikenal typomorphology. Bangunan menjadi bagian dari syiar dakwah pergerakan dan merepresentasikan Muhammadiyah. Untuk menelaah bangunan Muhammadiyah tersebut dilakukan dengan metode tipologi yang dikaitkan dengan arsitektur Islam dan keterhubungan antara bangunan Muhammadiyah satu dengan lainnya. Observasi bangunan dalam kesatuan tercipta dari spasialnya dan tentu saja dari massa bangunan itu sendiri dengan nilai dan makna yang dikandungnya sehingga mudah diidentifikasi.

Hedraningsih dalam Darmawan, menjelaskan unsur-unsur lain yang membentuk bangunan secara keseluruhan, yaitu skala, proporsi, irama, tekstur dan warna. [6]

Indikasi wujud khas arsitektur Islam yang masih terlihat sampai sekarang dapat dilihat pada Kauman. Rakhmawati mengidentifikasi rumah asli di Kauman Malang yang dapat dilestarikan. Dinamika bentuk tipe elemen dan ornament hunian arsitektural semakin 
bervariasi juga pada Kawasan Arab Ampel Surabaya.[5]

Dari hasil pengamatan Nur, kecederungan variasi arsitektural bangunan ini dipengaruhi gaya hidup, pendidikan dan status ekonomi dan sosial. Hal ini terlihat pada fasade bangunannya, dengan elemen yang paling dominan yang bermotif batu-bata. Tampilan pada pada pilar, dinding dan cornice nya sangat bernuansa Timur Tengah. Selain itu, terdapat ornamen dengan motif crenellation atau merlons sering dijumpai pada ornamen bangunan peribadatan Masjid. Untuk penggunaan model kusen bervariasi. Ada didesain dengan adopsi lengkung khas arsitektur Arab dan ada pula beberapa yang hanya berbentuk kotak persegi.[4]

\section{METODOLOGI}

Pendekatan yang dipakai dalam penelitian ini adalah pendekatan sejarah dan fenomenologi. Pendekatan sejarah digunakan untuk memaparkan gambaran kawasan pada masa lampau yang dikomparasikan dengan kondisi kawasan Muhammadiyah di kota-kota di Sulawesi Selatan. Sedangkan pendekatan fenomenologis merupakan di mana aspek subyektif dari perilaku obyek akan menjadi penekanan dalam penggalian informasi yang dibutuhkan. Teknik pengumpulan data diperoleh dari data primer berupa observasi, materi visual, wawancara dan data sekunder berupa studi literature, dan dokumen dari instansi. Metode analisa yang digunakan dalam penelitian ini dengan menggunakan metode fenomenologi dan sejarah serta dengan teknik sikronik dan diakronik reading serta memadukan metode urban morfologi dan tipologi.

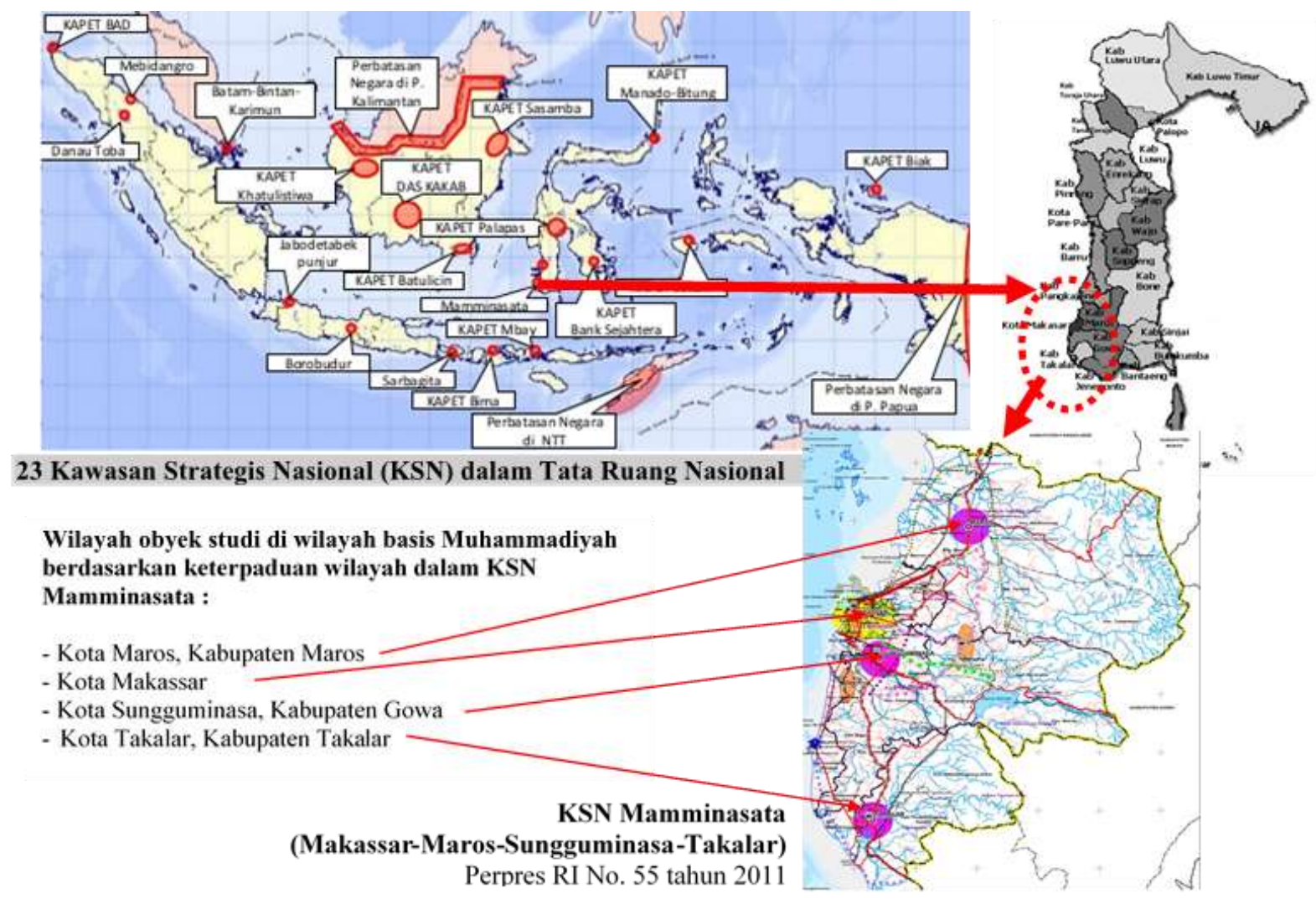

Gambar 2. Wilayah Mamminasata, Sulawesi Selatan Sebagai Obyek Wilayah Studi

(Sumber: Olahan Data, 2017) 


\section{IDENTIFIKASI KONDISI KAWASAN PUSAT ORIENTASI KEGIATAN (NODES) PERGERAKAN MUHAMMADIYAH}

\section{Perannya dan Kedudukannya Kawasan dalam Skala Kota}

1. Kota Makassar

Embrio Muhammadiyah bermula tahun 1922 dari seorang pedagang batik keturunan Arab yang berasal dari Madura bernama Mansyur Yamani. Beliau adalah anggota Muhammadiyah Cabang Surabaya yang membuka usaha perdagangan di Jalan Pasar Straat (kampung Butung) yang kemudian menjadi lokasi awal berdirinya Pimpinan Wilayah Muhammadiyah Sulawesi Selatan. Kampung Butung dalam pola ruang kota Makassar merupakan kawasan kota lama dimana titik awal perkembangan kota terbentuk. Pemindahan kantor PWM ditengarai dengan sejumlah faktor, seperti ketidaksinergian fungsi dan aktivitas terhadap lingkungan Butung. Sebagai nodes pusat perniagaan di Kota Lama dan kampung multi etnis, saat ini Butung menjadi alokasi kawasan perdagangan dan jasa skala regional, Kelurahan Butung menjadi magnet ekonomi di sekitarnya seperti adanya Pelabuhan Peti Kemas, terminal penumpang, jalan tol dan bangunan dengan fungsi perdagangan dan jasa. Selain itu, kantor PWM memerlukan lahan yang lebih luas untuk menampung aktivitas utama sebagai kantor representasi warga Muhammadiyah dan juga menampung kegiatan lain sebagai penunjang dakwah di masyarakat.

Lokasi PWM sekarang berada di Jalan Perintis Kemerdekaan termasuk dalam kawasan strategis Kawasan Pendidikan Tinggi Terpadu Rencana Tata Ruang Wilayah (RTRW) Kota Makassar 20152035. Pada ruas jalan Perintis Kemerdekaan tersebut terdapat beberapa kampus Perguruan Tinggi dan alokasi kantor pemerintahan yang melayani skala Provinsi. Pemindahan lokasi kantor menjadikan PWM Sulawesi Selatan sebagai bagian dari pemusatan dan pengembangan berbagai kegiatan pendidikan tinggi dan saling bersinergi dalam satu sistem ruang kawasan yang solid kota Makassar.

Saat ini pusat kegiatan Muhammadiyah menyebar di berbagai wilayah di Kota Makassar dalam bentuk amal usaha dalam bidang pendidikan, kesehatan dan sosial dengan total 71 unit. Persebaran cabang dan ranting Muhammadiyah tidak berdasarkan pada eksisting jumlah kecamatan di Kota Makassar.

Pergerakan Muhammadiyah dengan kaderisasinya telah memberikan sumbangsih pada pembentukan kota yang dibuktikan dengan adanya penamaan kampung Muhammadiyah dan berdirinya bangunan kepemilikan Muhammadiyah. Gejala awal yang diindikasi telah mengalami inflitrasi di Kota Makassar adalah adanya penamaan jalan Muhammadiyah di Makassar. Jalan Muhammadiyah ini berada di linkage kawasan kota lama, kawasan pelabuhan, Pecinan dan konstelasi kampung di Utara Kota Makassar. Pada ruas jalan Muhammadiyah ini terdapat beberapa fungsi fasilitas umum atas binaan khusus yang mengatasnamakan Muhammadiyah. Pada ruas jalan tersebut terdapat bangunan Amal Usaha Muhammadiyah terdiri dari 1 sekolah dasar, 2 Madrasah Tsanawiyah, 2 Madrasah Aliyah, 1 SMK dan 1 Panti Asuhan. Selain itu, dari hasil observasi, penamaan jalan Muhammadiyah lebih didasarkan karena daerah tersebut terdapat permukiman yang dihuni oleh penganut Muhammadiyah. Kehidupan yang berkelompok-kelompok inilah berpengaruh dengan didirikannya sejumlah insitusi Muhammadiyah yang letaknya berdekatan.

Jika dibandingkan dengan kawasan perkampungan Islam khususnya Muhammadiyah di Pulau Jawa, nodes Muhammadiyah di Kota Makassar sangat kecil dari segi luasan dan aktivitas yang diwadahi. Konsentrasi pergerakan hanya sebatas di Jalan Muhammadiyah. Lebar jalan 6,70 meter dengan status sebagai jalan lingkungan hanya menghubungkan jalan kolektor sekunder dan pusat-pusat perumahan.

Pada kawasan ini tidak tercipta koneksi sumbu visual yang dibentuk dari lingkungan Jalan Muhammadiyah dengan adanya kedudukan suatu bangunan seperti yang terjabarkan dalam teori Perancangan Kota. Berbeda dengan karakteristik perkampungan Islam di Pulau Jawa yang menempati kawasan yang strategis dan terintegrasi dengan bangunan penting seperti balaikota, keraton, masjid agung, lapangan atau alun-alun dan kawasan elit 
dan kawasan khusus lainnya. Pada linkage jalan Muhammadiyah tidak teridentifikasi fungsi lahan yang bernilai landmark ataupun yang mempengaruhi rona visual kawasan khususnya dan pada skala kota
Makassar secara keseluruhan. Jalan Muhammadiyah tidak mengaktualisasikan kawasan yang ikonik dan identik dengan fungsi tertentu di Kecamatan Wajo, terlebih lagi pada skala Kota Makassar.

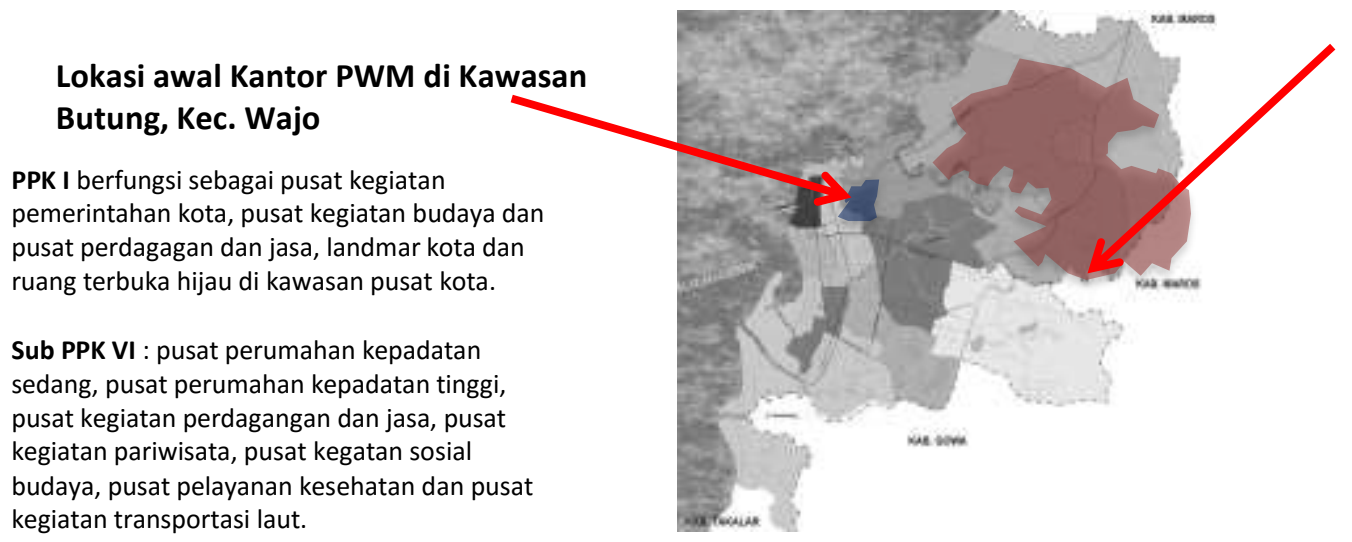

Lokasi Sekarang Kantor PWM di Jalan Perintis Kemerdekaan, Tamalanrea Jaya, Kec. Tamalanrea

PPK II berfungsi sebagai pusat kegiatan internasional, nasional dan regional dan ditetapkan sebagai kawasan pengembangan pesisir.

Sub PPK II : pusat perumahan kepadatan sedang, pusat perumahan kepadatan tinggi, pusat pelayanan penelitian dan pendidikan tinggi dan pusat kegiatan maritim.

Gambar 3. Tinjauan Tata Guna Lahan dan Tata Ruang Perubahan Lokasi Pimpinan Wilayah Muhammadiyah Sulawesi Selatan di Kota Makassar (Sumber: Olahan Data, 2017)

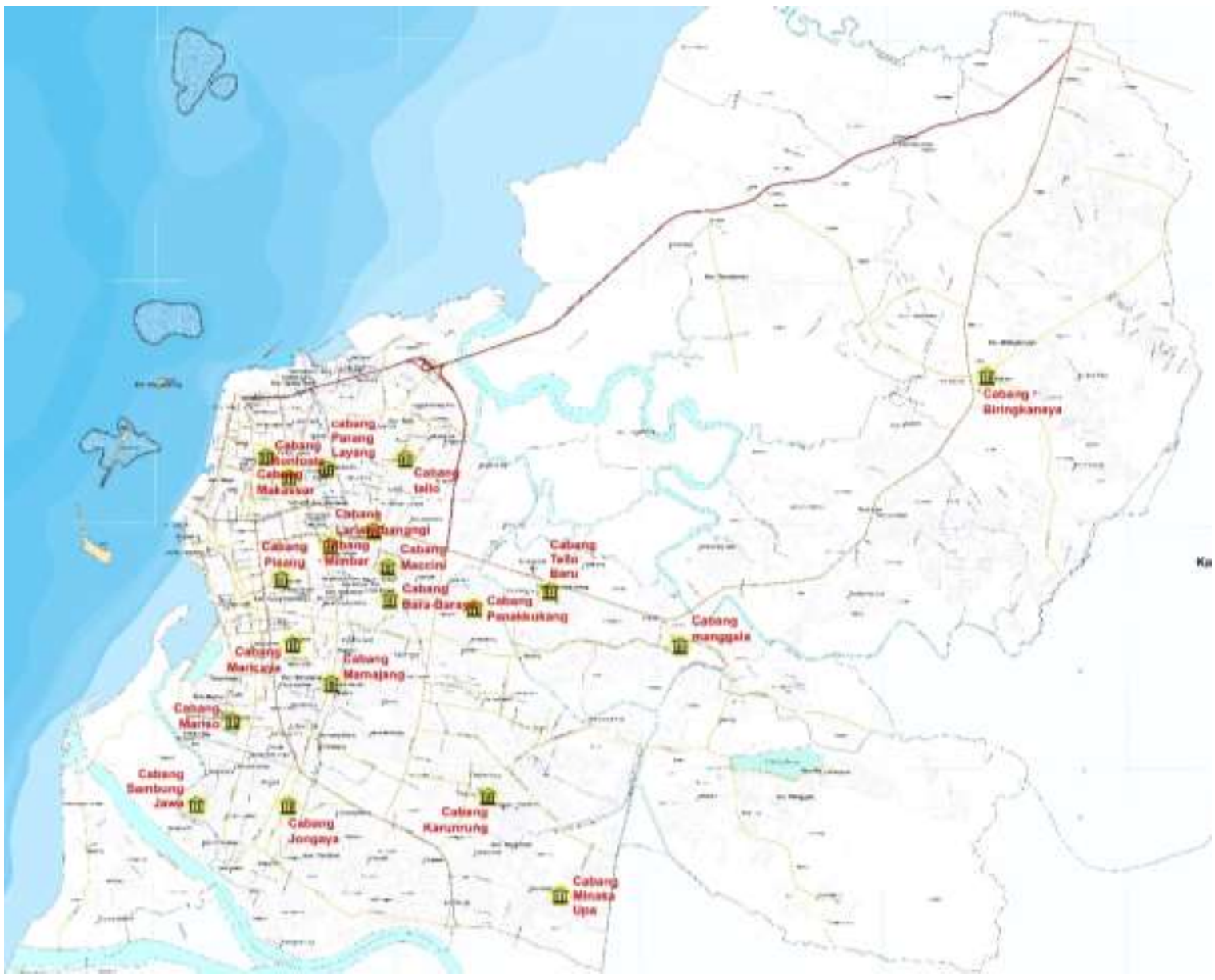

Gambar 4. Pemetaan Lokasi Pimpinan Cabang Muhammadiyah Kota Makassaar Sumber: Olahan Data, 2017 
2. Maros, Kabupaten Maros

Kabupaten Maros merupakan nodes dari beberapa tarekat. Namun demikian, eksistensi tarekat lain tidak menghalangi munculnya pemahaman lain yang berkembang dan berakulturasi dengan kebudayaan setempat, termasuk berdirinya institusi Muhammadiyah. Lokasi bangunan Muhammadiyah terdapat di kota Maros dan daerah Camba. Khusus di Kota Maros sendiri hanya ada 3 (tiga) unit fungsi bangunan Muhammadiyah yaitu berupa Pusat Dakwah Muhammadiyah Kabupaten Maros dan Mesjid Ta'mirul dan SD dan SMP Muhammadiyah.

Lokasi dari ketiga bangunan Muhammadiyah di Kota Maros tersebut berdekatan dalam suatu nodes kawasan Jalan Pisang. Di sebelah lahan Mesjid
Ta'mirul merupakan lahan wakaf yang dipersiapkan sebagai alokasi SMA dan Perguruan Tinggi Muhammadiyah. Bentuk tata guna lahan dari persebaran bangunan tersebut mengikuti pola jalan radial dengan pengikat Mesjid Ta'mirul sebagai poros aktivitas dakwah. Dalam aspek tata ruang kota, konsentrasi bangunan yang memusat pada suatu kawasan menjadikan daerah Turikale, Kota Maros menjadi urban tissue identitas Muhammadiyah. Namun, karena bangunan dan lahan yang relative tidak terlalu luas, sense of place yang tercipta pada skala ruang kota secara keseluruhan tidak terlalu kuat. Dari hasil pengamatan, nodes kawasan Muhamamdiyah Maros hanya dapat direspon dan diidentifikasi hanya segelintir warga yang mengenal bangunan Muhammadiyah di Kota Maros.

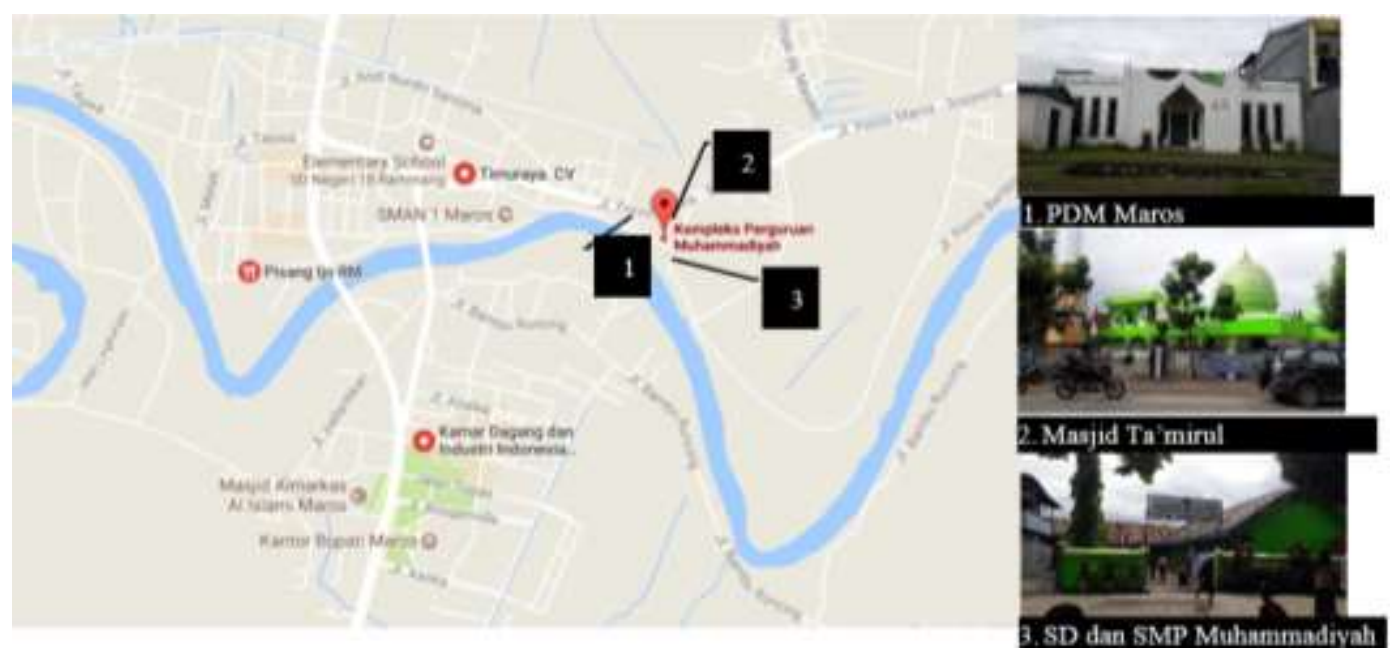

Gambar 5. Nodes bangunan Muhammadiyah di Maros, Kabupaten Maros (Sumber: Dokumentasi Pribadi, 2017)

3. Sungguminasa, Kabupaten Gowa

Perkembangan Sungguminasa sebagai ibukota Kabupaten Gowa tidak terlepas dari pertumbuhan Makassar sebagai kota metropolitan. Berdasarkan data persebaran bangunan AUM di Sulawesi Selatan, Kabupaten Gowa menempati urutan kedua terbanyak. Letak yang berbatasan langsung dengan Kota Makassar memudahkan akses dan distribusi pelayanan jasa kemasyarakatan. Kabupaten ini memiliki beberapa bangunan Kemuhammadiyahan, namun khusus di Kota Sungguminasa yang termasuk dalam Kecamatan Somba Opu, bangunan Muhammadiyah berupa SMA Muhammadiyah Sungguminasa, Mesjid Muhammadiyah Rahmatul Ummah, dan Kantor Pusat Dakwah Muhammadiyah. Di Kabupaten Gowa sendiri terdapat 56 sekolah yang tersebar di beberapa kecamatan.

Pusat Dakwah Muhammadiyah (PDM) Kabupaten Gowa tergolong strategis karena berada pada zonasi Istana Balla Lompoa yang menjadi ikon Kabupaten Gowa. PDM Gowa terletak pada jalan lingkungan, namun di linkage kawasan terdapat bangunan publik lainnya seperti SD dan SMP Aisyiah, kantor lurah Sungguminasa dan gereja Al Masih. Hal ini memperkuat kedudukan kantor PDM Gowa sebagai bangunan yang berpengaruh pada kawasan Sungguminasa.

Mesjid Rahmatul Ummah Muhammadiyah berada pada Jalan Poros Gowa-Makassar yang berstatus sebagai jalan arteri primer yang menghubungkan Kota Makassar dan 
Kabupaten Gowa. Mesjid berhadapan dengan Kodim dan beberapa bangunan pelayanan umum lainnya menjadikan bangunan ini bernilai penting secara spasial. Sedangkan SMA Muhammadiyah berada pada kawasan permukiman Pao- pao yang berbatasan dengan Kota Makassar. Eksistensi SMA ini tidak berpengaruh kuat dalam spatial kawasan permukiman, karena berada pada lorong ruas Jalan Bontotanga.
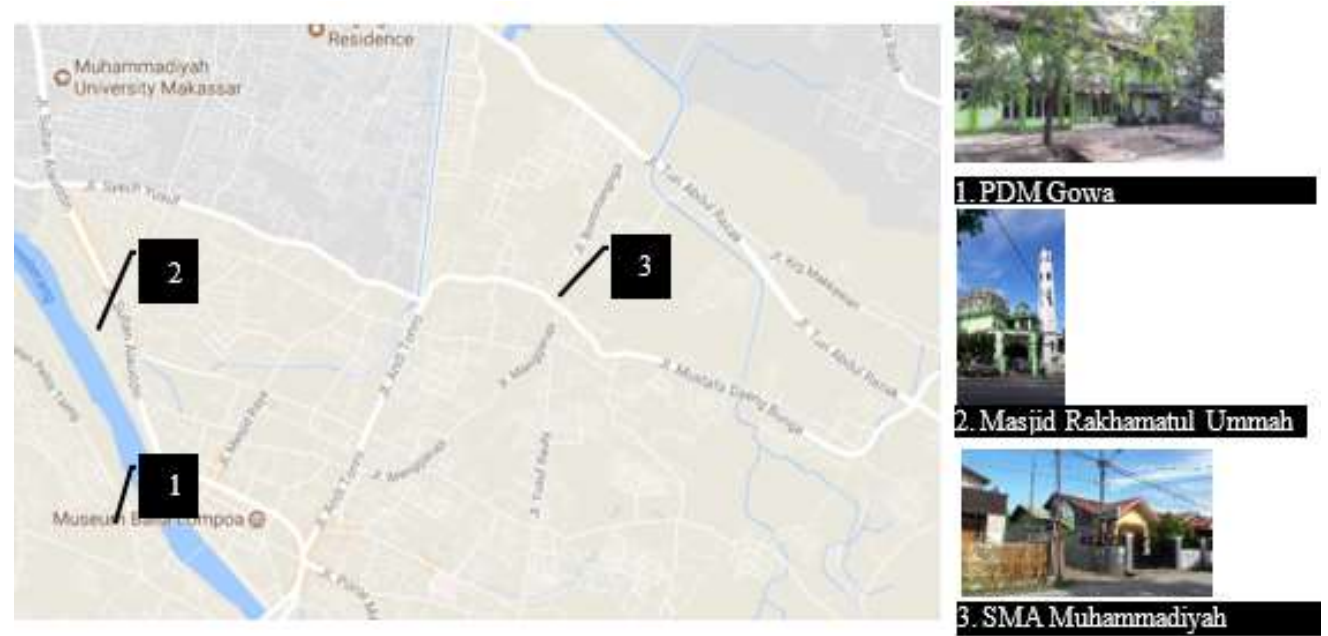

Gambar 6. Nodes sebaran bangunan Muhammadiyah di Kota Sungguminasa (Sumber: Dokumentasi Pribadi, 2017)

4. Takalar, Kabupaten Takalar

Lokasi bangunan Muhammadiyah di Kota

Takalar berjauhan dibatasi lintas Desa.

Dalam pemetaan ruang, eksistensi bangunan-bangunan tersebut tidak membentuk pola yang jelas dalam tata guna lahan kota. PDM Takalar berlokasi strategis di jalan poros Kabupaten Makassar-Takalar. Tepat di depan kantor PDM terdapat Mesjid Agung Takalar yang menjadi ikon kawasan. Kantor PDM saat ini masih dalam proses pembangunan, namun demikian masih dapat digunakan untuk mewadahi kegiatan kemuhammadiyahan secara berkala.

Alokasi bangunan Muhammadiyah tidak lepas dari peran para tokoh Muhammadiyah di Takalar. Bangunan amal usaha Muhammadiyah tersebut ada yang merupakan tanah wakaf untuk aktivitas pendidikan dan sosial kemasyarakatan Bangunan lebih berfokus pada sarana pendidikan yaitu SMP Muhammadiyah di Bonto Cindae, SMA Muhammadiyah di Soballabella dan TK Muhammadiyah di Salaka. Terdapat Mesjid Jami Nurul Badar yang menyatu dengan TK Muhammadiyah Salaka.

Dengan penempatan bangunan yang menyebar di wilayah kota, ruang pengikat yang memunculkan sense of place tidak terbentuk. Bangunan berasimilasi dengan kawasan perkampungan, bahkan cenderung mengalami degradasi nilai keruangan secara umum. Penamaan kampung Salaka ataupun kampung Bonto Cindae lebih dominan dibanding penyebutan keberadaan bangunan Muhammadiyah. 


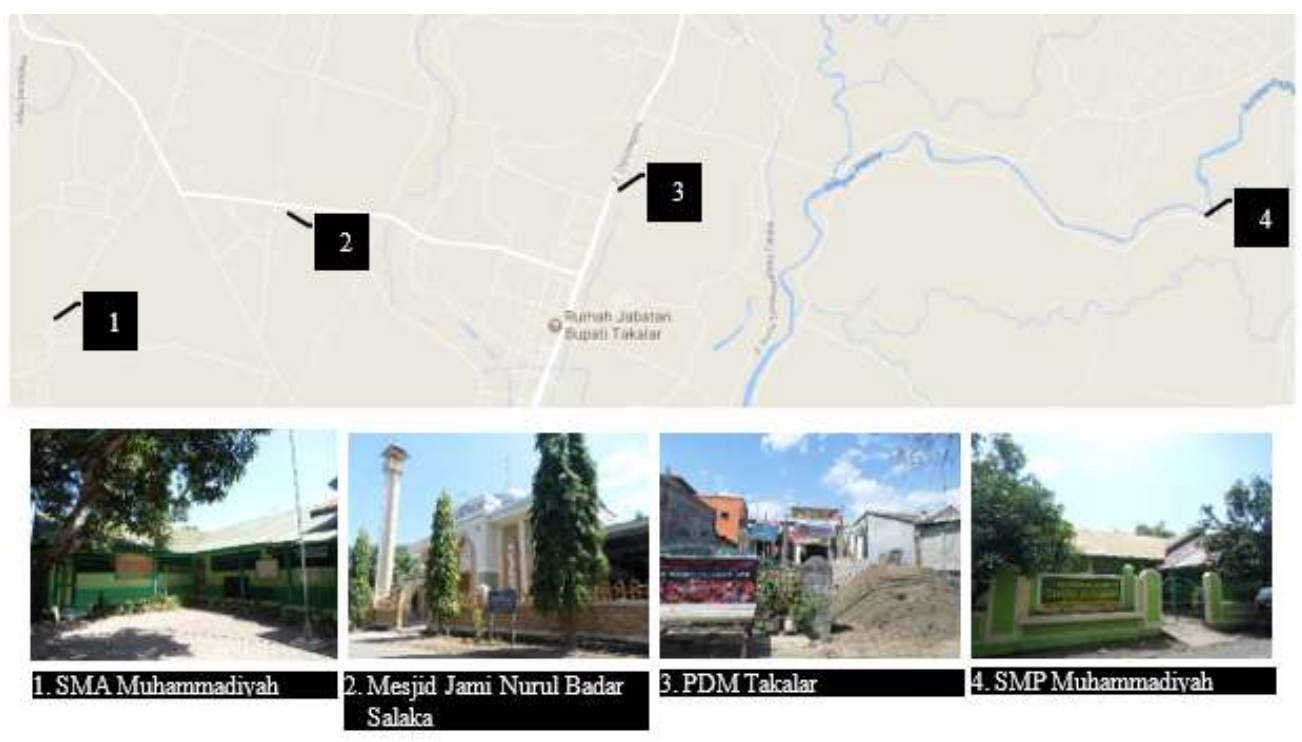

Gambar 7. Nodes bangunan Muhammadiyah di Takalar, Kabupaten Takalar

\section{Hubungan Nodes Pergerakan Muhammadiyah dalam Tata Ruang Kota}

Lokasi permukiman yang bernuansa Islam di Makassar, Sungguminasa, Maros dan Takalar sulit diidentifikasi karena tidak terkonsentrasi pada satu kawasan. Hal ini menyebabkan pemetaan kampung Islam, sebagaimana di daerah Pulau Jawa disebut Kauman, tidak terdapat di wilayah studi. Walaupun memiliki kesamaan morfologi kota lama dengan kotakota di Jawa yang memiliki Kauman, tetapi, di Makassar tidak memunculkan adanya konsentrasi permukiman homogen Islam yang berkarakter kuat.

Terlebih lagi di Sungguminasa, Maros dan Gowa yang tata guna lahannya berkembang tidak dalam konsep Planned Unit Design (PUD) hasil pengaruh ekspansi kolonial. Pola keruangan terbentuk secara linear mengikuti rute transportasi kabupaten yang mengarah utama ke Kota Makassar. Pada pusat kota di Sungguminasa, Maros dan Gowa tidak mengenal bentukan ruang terbuka alun-alun yang dikelilingi balaikota, masjid, gereja ataupun perkampung etnis tertentu. Hal ini menjadikan penzoningan ruang terlihat sporadic namun tetap mengikuti bentuk jalan.

\section{IDENTIFIKASI REPRESENTATIF DARI PERGERAKAN MUHAMMADIYAH}

\section{Tipologi Bangunan Muhammadiyah}

Nilai-nilai yang tidak teraga (intangible) yang diletakkan pada elit Muhammadiyah ini tersalurkan dalam bentuk fisik sarana amal usaha Muhammadiyah (AUM) yang mendukung ikrar diri Muhammadiyah dengan memfokuskan diri pada kerja-kerja sosial kemasyarakatan. Dalam perwujudan bangunan tersebut tidak hanya menunjukkan eksistensi Muhammadiyah di masyarakat, lebih dari itu secara tidak langsung juga merepresentatifkan pandangan dan wawasan organisasi. Representatif Muhammadiyah dan tampilan sarana AUM ini akan diinvetatisir berdasarkan tipologi bangunan dari elemenelemen arsitektur meliputi tampilan bangunan pada tampak depan langgam arsitektur, struktur dan material serta unsur skala, proporsi, dan warna.

1. Prototipe Kantor Pusat Dakwah Muhammadiyah Kota dan Kabupaten

Bangunan Pusat Dakwah Muhammadiah (PDM) menjadi refleksi fisik dari pergerakan Muhammadiyah pada suatu kota dan kabupaten. Semua PDM di empat wilayah obyek studi berbentuk segiempat simetris pada fasadenya menandakan bentuk arsitektur fungsionalis. Bentuk aksentuasi profil pada struktur tengah dan atas pada bangunan PDM tidak terlalu menonjol. Begitu pula pada tampilan warnanya. Di Maros, bangunan terlihat didominasi warna putih sehingga berkesan masih dalam proses pengerjaan. Di Takalar walaupun masih dalam proses pembangunan, dari tampilan visual juga mengarah pada prototipe bangunan formal lainnya yang minim aksentuasi. Untuk elemen warna, di Sungguminasa dan Makassar, bangunan PDM lebih banyak menggunakan warna hijau baik pada dinding ataupun ada atap 
bangunan. Hanya PDM Makassar yang memiliki langgam arsitekur modern yang cenderung berbeda. Tampilan arsitekturnya ditandai dengan tampilan material fasade yang berupa aluminium composite panel (ACP) dan penggunaan kaca.

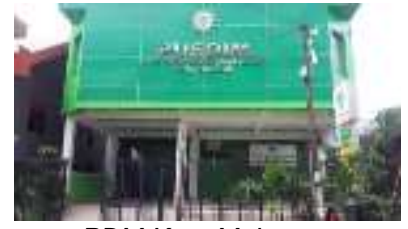

PDM Kota Makassar

PDM Kab. Maros

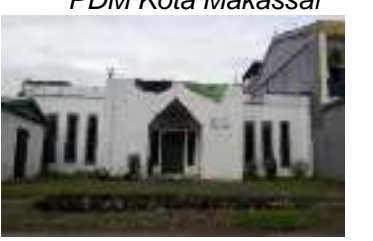

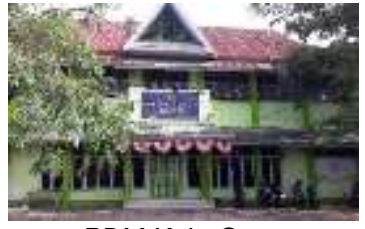

PDM Kab. Gowa

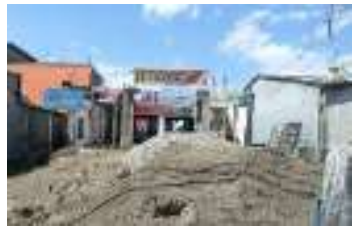

PDM Kab. Takalar
Gambar 8. Pusat Dakwah Muhammadiyah (PDM) di Wilayah Mamminasata

(Sumber: Dokumentasi Pribadi, 2017)

2. Prototipe Bangunan Sarana Pendidikan Sarana Pendidikan berupa jenjang SD, Madrasah Ibtidayah, SMP, Madrasah Tsanawiyah, SMA, Madrasah Aaliyah, SMK, dan Perguruan Tinggi bertipologi desain sarana Pendidikan yang baku pada umumnya. Bentuk denah mengikuti pola lahan dan berorientasi pada akses jalan utama di depannya. Terkecuali sekolah yang berada di Lorong dimana bentuk denahnya lebih fleksibel berdasarkan peruntukan jumlah kelas dan sirkulasi. Tipologi tampilan fasadenya berupa kotak baik bangunan berlantai 1 maupun berlantai 2 ke atas. Tampilan ciri Muhammadiyah hanya terlihat pada papan nama sekolah.

Secara keseluruhan, struktur tengah menggunakan material batu bata yang diplester dan diaci. Sedangkan pada struktur atas menggunakan beton yang dipadukan dengan atap seng dengan bentuk atap pelana. Aksentuasi pada bangunan sarana Pendidikan juga tidak menonjol pada aplikasi profil secara visual. Penggunaan warna dapat dikatakan sebagai salah satu unsur estetika yang memecah kemonotonan desain bangunan Pendidikan.

Satu-satunya sarana pendidikan yang tidak menggunakan pakem bentuk tersebut adalah Gedung Menara Iqro Kampus Universitas Muhammadiyah Makassar di Jalan Sultan Alauddin. Namun demikian,
Gedung Menara lqro tidak termasuk dalam data persebaran Pimpinan Cabang Muhammadiyah di Makassar.
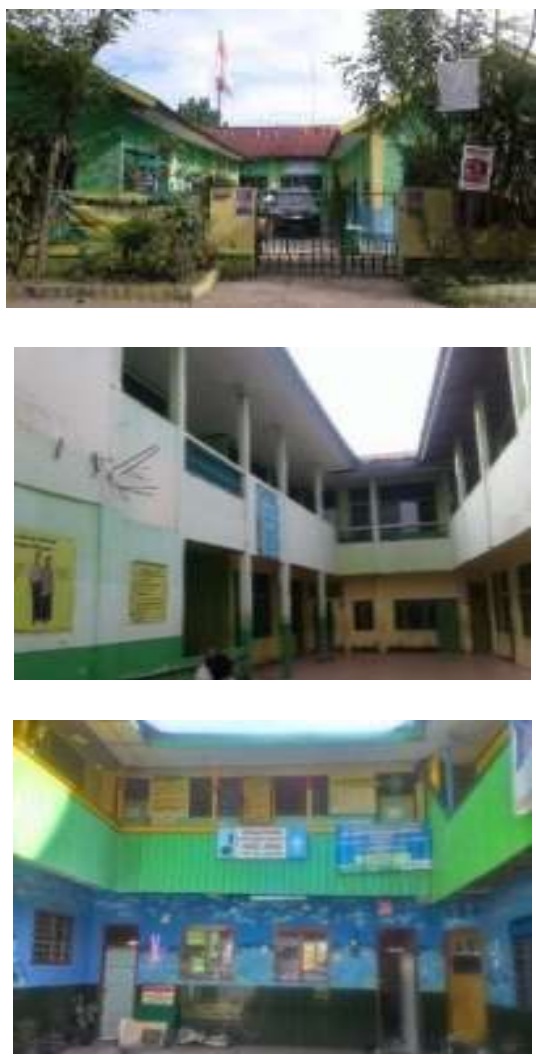

Gambar 9. Bangunan Sarana Pendidikan Muhammadiyah

(Sumber: Dokumentasi Pribadi, 2017)

3. Prototipe Bangunan Sarana Sosial

Sarana sosial yang diambil sebagai sampel adalah koperasi dan kantor majelis. Namun demikian, fungsi bangunan koperasi dan kantor majelis ini tidak dapat secara detail diidentifikasi karena menyatu dengan bangunan fungsi lain berupa masjid dan sekolah.

4. Prototipe Bangunan Mesjid

Secara keseluruhan tampilan bangunan cenderung konvensional yang lebih mengarah pada pendekatan fungsionalis baik desain maupun materialnya. Struktur atas didominasi bentuk kubah dengan modifikasi atap pelana. Struktur tengah berupa batu bata dengan tutupan plaster dan acian. Aksentuasi diaplikasikan pada penggunaan profil dinding, kanopi, dan tiang atau pilar masjid. Dominasi warna hijau dan putih tetap menjadi ikonik bangunan masjid Muhammadiyah yang diikuti dengan penambahan papan nama masjid. Dari semua masjid yang berada di wilayah Pimpinan Cabang dapat diindetifikasi bahwa Mesjid Jongaya, Mesjid Al Ikhwan dan Mesjid Baitulrahman Tallo 
berkesan atraktif. Ciri arsitektur yang berbeda dan lebih berani keluar dari prototipe bangunan masjid pada umumnya di Kota Makassar.
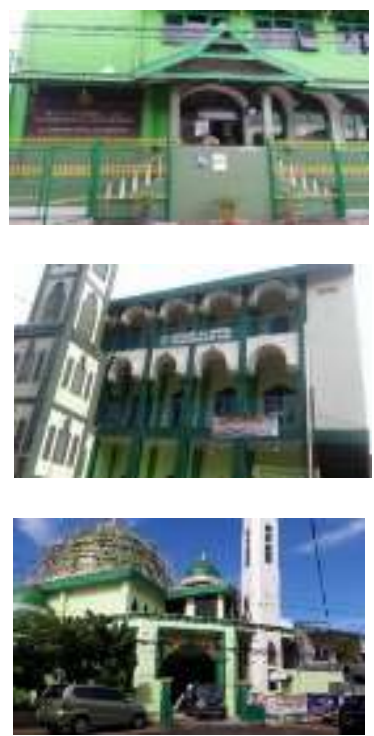

a) Mesjid dengan Langgam Arsitektur yang
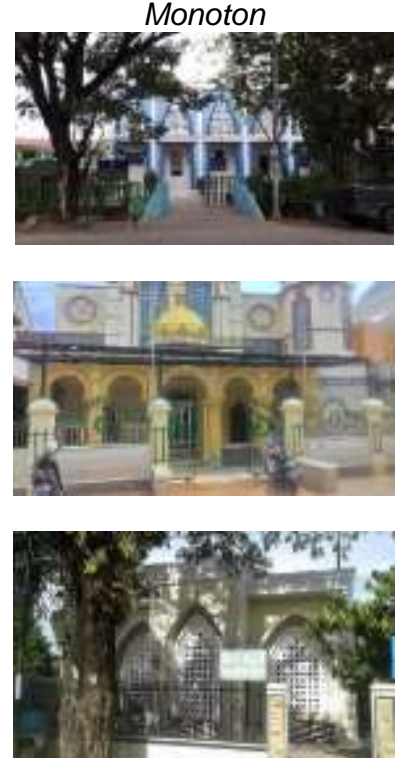

b) Mesjid dengan Langgam Arsitektur yang Variatif

Gambar 10. Prototipe Tampilan Mesjid Muhammadiyah

(Sumber: Dokumentasi Pribadi, 2017)

5. Prototipe Bangunan Sarana Kesehatan

Dari purposive sampling sarana kesehatan, diidentifikasi bahwa tampilan depan bangunan ditutupi dengan material Aluminium Composite Panel Alcucopan (ACP). Karakter material ACP merepresentatifkan waktu renovasi bangunan dalam kurun di bawah 10 tahun terhadap usia bangunan. Pertimbangan penggunaan material ACP ini karena memiliki struktur bahan yang aman, nyaman, ringan, kuat dan awet. Selain itu tergolong aman karena bersifat nontoxic (tidak beracun), nyaman bias mengurangi kebisingan terkhusus untuk bangunan kesehatan. Selain itu ACP juga tahan terhadap cuaca yang memudahkan aspek perawatan.
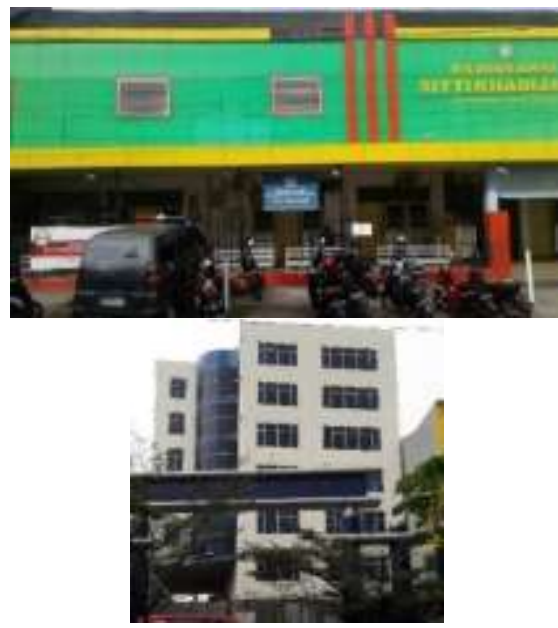

Gambar 11. Bangunan Sarana Kesehatan Muhammadiyah

(Sumber: Dokumentasi Pribadi, 2017)

\section{KESAN (SENSE OF PLACE) DAN KEDUDUKAN BANGUNAN TERHADAP LINKAGE SEKITARNYA}

Dari hasil identifikasi bangunan Muhammadiyah di Makassar, Sungguminasa, Maros dan Takalar, eksistensi bangunan Muhammadiyah tidak memiliki aksentuasi yang kuat terhadap linkage di sekitarnya. Hanya bangunan Menara Iqro bagian dari Kampus Universitas Muhammadiyah Makassar dapat dikatakan sebagai bangunan yang menjadi ikon landmark di Makassar Selatan. Gedung lqro yang berlantai 18 ini menjadi gedung tertinggi di Kawasan Makassar Selatan. Secara umum, tidak ada desain khusus yang ditampilkan pada bangunan ini, kecuali penggunaan dominasi material ACP yang berwarna biru khas Muhammadiyah. Gedung Iqro ini berfungsi sebagai gedung pertemuan, gedung kuliah dan hotel. 


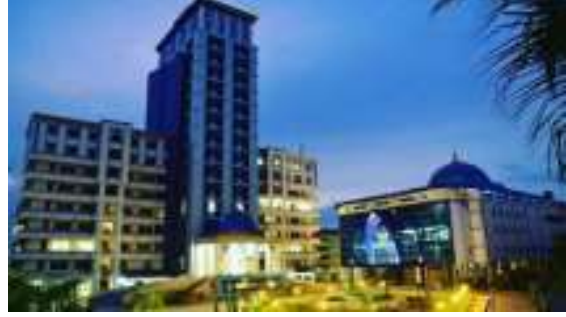

\section{Gambar 12. Menara Iqro Universitas} Muhammadiyah Makassar

(Sumber: www.unismuh.ac.id, 2017)

Bangunan Muhammadiyah lain yang berpotensi menjadi ikon adalah rumah sakit Muhammadiyah yang baru diresmikan tahun 2017 ini. Status bangunan Rumah Sakit yang masih dalam proses pembangunan dapat menjadi benchmark pada jalur linear ruas Jalan Hertasning Baru. Selain itu, bangunan sarana kesehatan seperti Rumah Sakit Khadijah berada pada jalan dengan status kolektor primer atau jalan protokol di Kota Makassar. Hal ini atas dasar kemudahan aksesibilitas transportasi dan pergerakan mobilitas publik. Lokasi yang strategis ini secara tidak langsung menjadikan rumah sakit Muhammadiyah juga berpotensi dalam penciptaan ruang kawasan.

Dasar penggunaan warna dominasi putih dan hijau hanya sebatas pada analogi dari tampilan logo dari Matahari Muhammadiyah. Warna Putih pada seluruh gambar matahari melambangkan kesucian dan keikhlasan, sedangkan warna Hijau yang menjadi warna dasar melambangkan kedamaian dan dan kesejahteraan. Pemilihan warna ini sejalan dengan aplikasi psikologis warna dalam arsitektur. Simbolis warna diharapkan menjadi unsur tersirat pada bangunan yang mengemban nilai keteladanan Muhammadiyah.

\section{KESIMPULAN}

Kesamaan morfologi kota lama dengan kotakota di Jawa yang memiliki perkampungan Islam Kauman, tidak terbukti pada pembentukan konsentrasi permukiman homogen Islam yang berkarakter kuat di Kota Makassar. Pada pusat kota di Sungguminasa, Maros dan Gowa juga tidak mengenal bentukan ruang pengaruh kolonial. Pola keruangan terbentuk secara linear mengikuti rute transportasi kabupaten yang mengarah utama ke Kota Makassar. Hal ini pula yang menyebabkan penyebaran tata guna lahan tidak memusat termasuk tidak adanya kampung Islam, terlebih lagi tidak adanya infiltrasi kawasan yang identik dengan Muhammadiyah yang secara makro mempengaruhi konsep perancangan kota di obyek studi.

Bangunan - bangunan kemuhammadiyah yang tersebar di wilayah obyek studi tidak memunculkan adanya tipologi ikonik bangunan Muhammadiyah. Hal ini karena, pada umumnya dalam satu bangunan menampung fungsi sarana lain sehingga satu bangunan berkesan krisis identitas dalam tampilan arsitekturnya. Desain sarana pendidikan, kesehatan dan sosial lebih menekankan pada aspek fungsional dibanding mengaplikasikan langgam arsitektur tertentu. Namun, eksplorasi desain kental dengan berbagai langgam arsitektur lebih terlihat pada bangunan masjid Muhammadiyah. Bangunan ikonik yang berpengaruh terhadap keruangan kawasan di obyek studi antara lain kampus Universitas Muhammadiyah Makassar, rumah sakit bersalin Khadijah dan rumah sakit Muhammadiyah. Hal ini karena desain bangunan ikonik, menciptakan landmark terhadap lingkungannya dan lokasi bangunan yang strategis berada pada minimal status jalan kolektor sekunder. Sebagai suatu organisasi dan pergerakan sosial keagamaan Islam yang berpengaruh di Indonesia, sudah saatnya Muhammadiyah memiliki simbolisasi dan ciri khas bangunan yang menjadi prototipe di wilayah Muhammadiyah.

\section{UCAPAN TERIMA KASIH}

Penelitian ini dibiayai dari Hibah Penelitian Muhammadiyah Abad Kedua tahun 2017. Penulis mengucapkan terima kasih kepada Majelis Pendidikan Tinggi Peneliltian dan Pengembangan Pimpinan Pusat Muhammadiyah.

Terima kasih kepada Dewan Pengurus Pusat, Wilayah Muhammadiyah di Kota Makassar, Maros, Sungguminasa dan Takalar.

Terima kasih kepada Prodi Arsitektur Fakultas Teknik Universitas Muhammadiyah Makassar yang telah memberikan fasilitas dan dukungan demi terselesaikannya kegiatan penelitian ini.

\section{DAFTAR PUSTAKA}

[1] Wijanarka (2004). Teori Desain Kawasan Bersejarah, suatu Dasar Meweujudkan Desain Pelestarian dan Pengembangan Kawasan Bersejarah dengan Semarang 
sebagai Obyek Kajian, Palangkaraya. Universitas Palangkaraya.

[2] Darban, Ahmad Adaby. (2011) Sejarah Kauman: Menguak Identitas Kampung Muhammadiyah. Suara Muhammadiyah, Yogyakarta

[3] Depari, Catharina Dwi Astuti (2012). Transformasi Ruang Kampung Kauman Yogyakarta sebagai Produk Sinkretisme Budaya. Jurnal Arsitektur Komposisi, Volume 10, Nomor 1, April 2012. http://ojs.uaiy.ac.id [23 November 2006].

[4]Nur, Khilda, Wildana (2010). Tipomorphologi dan Kekhasan Tata Ruang Rumah Arab, di Ampel Surabaya, Tesa Arsitektur: Jurnal of Architectural Discourses 8: 1:

[5] Rakhmawati, Ekahayu, Antariksa, Usman, Fadly. (2009). Pola Permukiman Kampung Kauman Kota Malang. Arsitektur eJournal, Volume 2 Nomor 3, November 2009. https://www.researchgate.net [23 November 2016]

[6] Darmawan, Edy dan Ratnawati, Ariko. (2005). Bentuk, Makna, Ekspresi Arsitektur Kota dalam Suatu Kajian Penelitian, Semarang. Badan Penerbitan Universitas Diponegoro

\section{BAHAN BACAAN TAMBAHAN}

Darjosanjoto, Endang T.S, (2006). Penelitian Arsitektur di bidang Perumahan dan Permukiman, Surabaya. ITS Press

Nas, Peter, JM, (1986). The Indonesian City: Studies in Urban Development and Planning, USA. Foris Publication

Sholihah, Kurniati Alimi (2007). Peranan Muhammadiyah dalam Pergerakan Nasional dan Pendidikan Nasional di Indonesia, Skripsi, Universitas Malang

Soetomo, Sugiono, (2009). Urbanisasi dan Morfologi-Proses Perkembangan Peradaban dan Wadah Ruang Fisiknya: Menuju Kehidupan Ruang vang Manusiawi, Yogyakarta. Graha IImu

Syahputra, Hikmawan (2014), Peran Politik Muhammadiyah Tahun 2010-2014, Jurnal IImu Pemerintahan Univeristas Brawijaya, Malang 
